\title{
Evaluation The Combustion Properties of The Modified Polypropylene
}

\author{
A. A. Younis \\ Fire and Explosion Protection (FEP) Lab, National \\ Institute for Standards (NIS), Tersa St., Alharam, \\ Giza, Egypt, P.O Box: 136 Giza, Code No. 12211.
}

\begin{abstract}
A NEW flame-retardant compounds A; synthesized from . A....phenyltrimethoxysilane (PTMS) and potassium-montmorillonite (K-MMT), B; synthesized from 3-glycidoxypropyl)trimethoxysilane (3GPTMS) and potassium-montmorillonite (K-MMT), and C; synthesized from potassium-montmorillonite (K-MMT) that prepared by using solgel technique. TWIN-SCREW EXTRUDER was used to blend polypropylene (PP) with different weight percentage of polymers A, B, and $\mathrm{C}$. In this paper the thermal properties of composites $\mathrm{A}, \mathrm{B}$, and $\mathrm{C}$ were examined by using differential scanning calorimeter (DSC). The combustion properties of the composites $\mathrm{PP} / \mathrm{A}, \mathrm{PP} / \mathrm{B}$, and $\mathrm{PP} / \mathrm{C}$ were evaluated by the cone calorimeter (CC) at heat flux $35 \mathrm{~kW} / \mathrm{m}^{2}$. The decreasing Mass Loss Rate (MLR), Heat Release Rate (HRR), and Peak Heat Release Rate (pHRR) of the blend specimens compared to the pure PP (blank) after combustion indicated the main role of the blend composites in improving the ignition properties of the PP. Hence, the fire risk of the PP can be ignored with blending with composites A, B, and $\mathrm{C}$.
\end{abstract}

Keywords: Flame retardant, Polypropylene, Cone calorimeter, Heat release rate, Differential scanning calorimeter.

PP is the most extensively used polymer, it is easily and highly flammable due to the chemical constitution [1], but it is used in many applications, such as textile, furniture, medicines, automotive products, car industry, interior decoration [2-5]. Aromatic hydrocarbons such as xylene and toluene are used to dissolve PP at temperature above $105^{\circ} \mathrm{C}$. Montmorillonite (MMT) is widely used in synthesis new composites by blending different weight percentage to the polymer such as polypropylene and polystyrene. The combustion characteristics were determined by cone calorimeter instrument [6-14].

Cone calorimeter is a calorimetric measurement method used to evaluate the flame retardancy of specimens [15]. It depends on measuring the decreasing oxygen concentration during specimen ignition. The $\mathrm{CC}$ instrument has exhaust duct used to measure the gas flow as carbon monoxide $(\mathrm{CO})$ and carbon dioxide

Corresponding Author Email: dr_ahmedabdee@yahoo.com

Doi: 10.21608/ejchem.2017.608.1006

(C)2017 National Information \& Documentation Center (NIDOC) 
$\left(\mathrm{CO}_{2}\right)$. This test is an important due to measure the quantity of heat release of the specimen surface. In previous work [16], composites PP/A, PP/B, and PP/C were prepared. It is proved that blended PP with different weight percentage of compounds $\mathrm{A}, \mathrm{B}$, and $\mathrm{C}$ improved the mechanical properties and thermal stability than blank specimen. Blended montmorillonite with a polymer lead to decrease the mass loss rate and pHRR in cone calorimeter test [17-22]. In the present work, the thermal and combustion behaviors of the composites PP/A, $\mathrm{PP} / \mathrm{B}$, and $\mathrm{PP} / \mathrm{C}$ were estimated by the cone calorimeter instrument. It is the most effective and widely used instrument for measuring the Heat Release Rate, Peak Heat Release Rate, Mass Loss Rate (MLR), Time To Ignition (TTI), Time To Flameout (TTF) and other fire properties [23, 24].

\section{Materials and Methods}

\section{Materials}

Polypropylene was purchased as pellets from the Oriental Petrochemicals Company (OPC, Egypt). Potassium montmorillonite was supplied by Ke Yan Company (Anhui, China). Both of PTMS (94\%, Aldrich) and 3-GPTMS (97\%, Alfa Aesar) were used as received without further purification.

\section{Preparation of the PP composites}

The composites were synthesized when PP with different percentage (97.5, 95, and 92.5\%) was blended with $\mathrm{A}(\mathrm{P} 1 ; 2.5 \%, \mathrm{P} 2: 5.0 \%$, and $\mathrm{P} 3: 7.5 \%), \mathrm{B}(\mathrm{C} 1$ : 2.5\%, $\mathrm{C} 2: 5.0 \%$, and $\mathrm{C} 3: 7.5 \%)$ and $\mathrm{C}(\mathrm{M} 1: 2.5 \%$, M2: $5.0 \%$, and $\mathrm{M} 3: 7.5 \%)-$ polymers [16] using a Newplast Twin Screw extruder (India) at a screw speed of $35 \mathrm{rpm}$. There are three zones of mixing, their temperature were $\mathrm{T}_{1}=185^{\circ} \mathrm{C}$, $190^{\circ} \mathrm{C}$ and $\mathrm{T}_{3}=190^{\circ} \mathrm{C}$, respectively. The obtained dried pellets of the compounds were injected using a Morgan Press Injection Instrument (USA) at $160^{\circ} \mathrm{C}$ for nozzle zone and a barrel zone at injection pressure $120 \mathrm{MPa}$, holding pressure 90 $\mathrm{MPa}$ for time 20sec and cooling time 10sec to produce the samples [25].

TABLE 1. The PP polymer and their composites.

\begin{tabular}{|c|c|c|c|c|c|c|c|c|c|}
\hline \multirow{2}{*}{$\begin{array}{c}\text { PP } \\
/ \mathrm{g}\end{array}$} & \multicolumn{3}{|c|}{ PTMS/K-MMT } & \multicolumn{3}{c|}{ GPTMS/K-MMT } & \multicolumn{3}{c|}{ K-MMT } \\
\cline { 2 - 10 } & $\begin{array}{c}\mathrm{P} 1 \\
/ \mathrm{g}\end{array}$ & $\begin{array}{c}\text { P2 } \\
/ \mathrm{g}\end{array}$ & $\begin{array}{c}\mathrm{P} 3 \\
/ \mathrm{g}\end{array}$ & $\begin{array}{c}\text { C1 } \\
/ \mathrm{g}\end{array}$ & $\begin{array}{c}\mathrm{C} 2 \\
/ \mathrm{g}\end{array}$ & $\begin{array}{c}\mathrm{C} 3 \\
/ \mathrm{g}\end{array}$ & $\begin{array}{c}\text { M1 } \\
/ \mathrm{g}\end{array}$ & $\begin{array}{c}\text { M2 } \\
/ \mathrm{g}\end{array}$ & $\begin{array}{c}\text { M3 } \\
/ \mathrm{g}\end{array}$ \\
\hline 100 & ---- & ---- & ---- & ---- & ---- & ---- & ---- & ---- & ---- \\
\hline 97.5 & 2.5 & ---- & ---- & 2.5 & ---- & ---- & 2.5 & ---- & ---- \\
\hline 95.0 & ---- & 5.0 & ---- & ---- & 5.0 & ---- & ---- & 5.0 & ---- \\
\hline 92.5 & ---- & ---- & 7.5 & ---- & ---- & 7.5 & --- & ---- & 7.5 \\
\hline
\end{tabular}

Differential scanning calorimeter (DSC)

DSC analysis was achieved on DSC-50 (Shimadzu, Japan) instrument. It is used to determine the peak, onset, and heat flow $(\Delta H)$ of composites in a range from $30-650^{\circ} \mathrm{C}$ with heating rate $10^{\circ} \mathrm{C} / \mathrm{min}$ and flow rate $30 \mathrm{ml} / \mathrm{min}$ in $\mathrm{N}_{2}$ gas [26].

Egypt. J. Chem. 60, No. 1 (2017) 


\section{Instrument technique}

The cone calorimeter instrument is a significant instrument to investigate the ignition behavior of materials [27,28]. It is described in the international standard ISO 5660-1, using a Fire Testing Technology, UK Cone Calorimeter [29,30]. In this test the specimen with dimension $7.5 \mathrm{~cm} \times 7.5 \mathrm{~cm} \times 0.2 \mathrm{~cm}$ was covered with aluminum foil, placed on a holder which wrapping with aluminum foil to expose the upper surface of the specimen to the radiant heater only. Aluminum foil playing a significant role in ensuring good control of the burning process [31].

The surface area of the specimen exposed to a constant irradiance level $\left(35 \mathrm{~kW} / \mathrm{m}^{2}\right)$ in horizontal configuration from a truncated cone heater to ignite the tested specimen. A spark igniter above the test samples ignites any flammable gases produced by the devolatilization of the test sample. This test is considered a small-scale fire test, which provide us with data about: time to ignition (TTI, s), heat release rate $\left(\mathrm{HRR}, \mathrm{kW} / \mathrm{m}^{2}\right)$, and peak heat release rate $\left(\mathrm{pHRR}, \mathrm{kW} / \mathrm{m}^{2}\right)$, and mass loss rate (MLR) [32-34]. The uncertainty of the cone calorimeter test was about $\pm 5 \%$. The peak of HRR of specimens used to determine the potential behavior during the ignition. Since the specimen has lower values for pHRR its fire resistance [35].

\section{Results and Discussion}

DSC results

The thermal analysis test (DSC) was taken to study the change of the materials with temperature for blank and blened specimens. The results were tabulated in Table 2.

TABLE 2. Differential thermal analysis of blank and blended specimens.

\begin{tabular}{|c|c|c|c|c|c|c|}
\hline \multirow[b]{2}{*}{ Specimens } & \multicolumn{3}{|c|}{ First Peak } & \multicolumn{3}{|c|}{ Second Peak } \\
\hline & $\begin{array}{c}\text { Peak/ } \\
\left({ }^{\circ} \mathrm{C}\right)\end{array}$ & $\begin{array}{c}\text { Onset/ } \\
\left({ }^{\circ} \mathrm{C}\right)\end{array}$ & $\begin{array}{c}\text { Heat flow/ } \\
(\mathrm{J} / \mathrm{g})\end{array}$ & $\begin{array}{c}\text { Peak/ } \\
\left({ }^{\circ} \mathrm{C}\right)\end{array}$ & $\begin{array}{c}\text { Onset/ } \\
\left({ }^{\circ} \mathrm{C}\right)\end{array}$ & $\begin{array}{c}\text { Heat flow/ } \\
(\mathrm{J} / \mathrm{g})\end{array}$ \\
\hline $\mathbf{P P}$ & 167.10 & 153.91 & -38.09 & 445.58 & 421.58 & -146.23 \\
\hline $\mathrm{C1}$ & 168.85 & 157.58 & -33.41 & 458.26 & 434.90 & -135.50 \\
\hline M1 & 171.83 & 161.62 & -33.93 & 458.40 & 431.17 & -170.34 \\
\hline P1 & 170.25 & 161.74 & -38.26 & 458.21 & 431.33 & -194.53 \\
\hline $\mathrm{C2}$ & 170.22 & 159.73 & -35.73 & 453.89 & 428.01 & -194.71 \\
\hline M2 & 168.93 & 157.80 & -30.46 & 457.73 & 435.69 & -148.97 \\
\hline $\mathbf{P 2}$ & 170.03 & 156.18 & -40.39 & 446.93 & 422.59 & -203.64 \\
\hline C3 & 169.48 & 158.10 & -38.18 & 451.93 & 428.74 & -211.85 \\
\hline M3 & 170.09 & 157.88 & -35.66 & 425.18 & 392.17 & -212.95 \\
\hline P3 & 169.97 & 156.75 & -30.69 & 439.53 & 414.94 & -182.82 \\
\hline
\end{tabular}


The thermal characteristics were achieved in two analysis stages. In the first stage of analysis, sharp endothermic peaks appeared in the degree between $150-175^{\circ} \mathrm{C}$ for all specimens due to water evaporation. A sharp endothermic peak in the heat flow range between -30 and $-41 \mathrm{~J} / \mathrm{g}$ appears at $167.10^{\circ} \mathrm{C}$ in case of PP then increased recording the highest degree in case of M1 with shifting in the right direction for all blend specimens (Fig. 1). Different degradation products appear in the second stage since, the heat flow increased recording the highest value $(-212.95 \mathrm{~J} / \mathrm{g})$ in the case of specimen M3, but the peak has appeared at the lowest degree $425.18^{\circ} \mathrm{C}$.

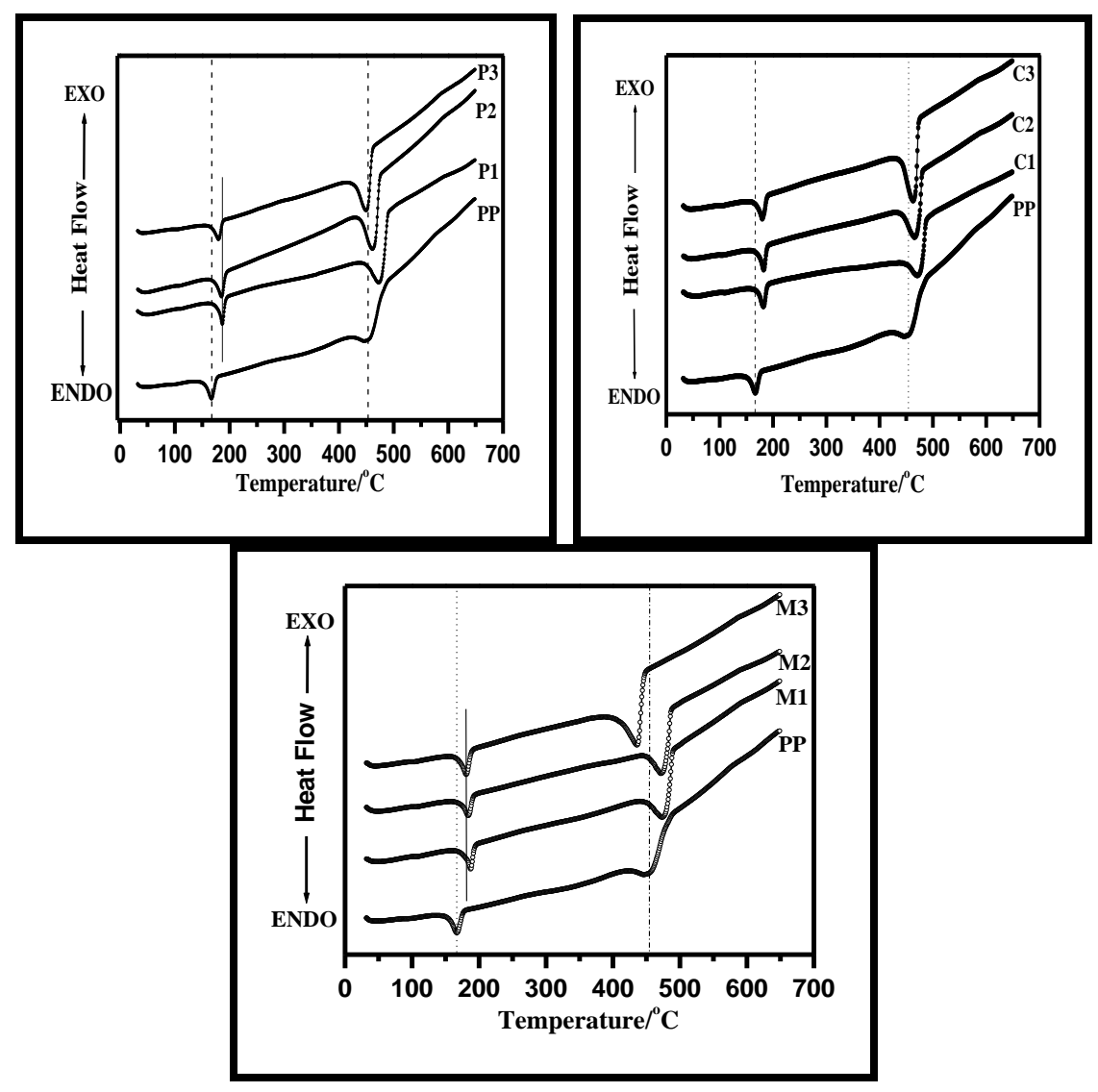

Fig. 1. DSC thermogram of the blank and blended composites.

\section{Combustion behavior of the composites}

Time to ignition (TTI)

The flaming behavior of the specimens was investigated by TTI [36]. The best improvement in combustion retardancy is achieved when the TTI value increased and pHRR decreased. Figure 2 illustrates that the TTI increased as the weight $\%$ of compounds $\mathrm{A}, \mathrm{B}$, and $\mathrm{C}$ increased during the blending with $\mathrm{PP}$. The 
TTI of composites C3, M3, and P3 are increased by 37, 34, and 31\% compared to the other. It may return to interchemical reaction between PP and compounds $\mathrm{A}, \mathrm{B}$, and $\mathrm{C}$, respectively. The direct contact between phenyl group and silan lead to consume more time to ignition until this bonds cracking. The fire performance index (FPI) was calculated from the ratio between the TTI and the pHRR [37]. The best fire retardant performance is the higher FPI value [38]. Based on FPI results, the fire safety of the specimens can be ranked as: $\mathrm{C} 3>$ $\mathrm{C} 2=\mathrm{M} 3=\mathrm{P} 2=\mathrm{P} 3>\mathrm{C} 1=\mathrm{P} 1=\mathrm{M} 1=\mathrm{M} 2>\mathrm{PP}$.

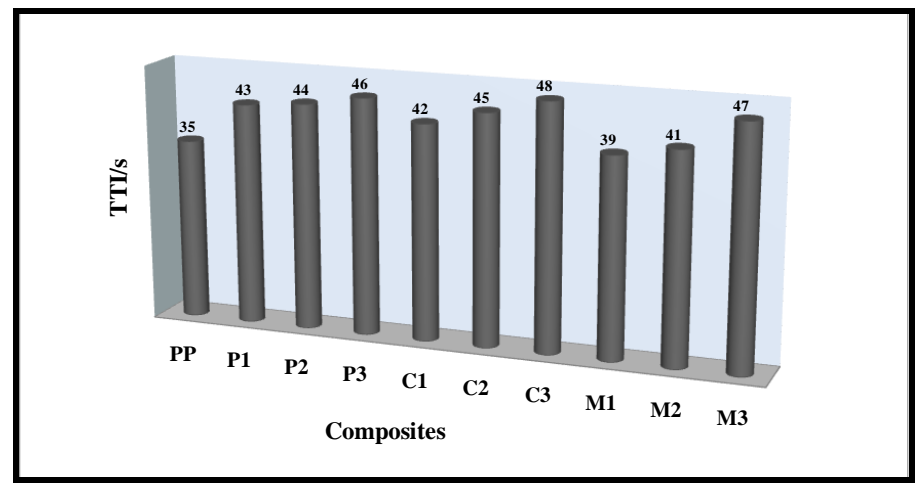

Fig. 2. Time to ignition versus composites at heat fluxes $35 \mathrm{~kW} / \mathrm{m}^{2}$.

\section{Heat Release Rate (HRR)}

HRR plays an important role in the determination the fire risk because it is determined the energy release and the maximum heat release rate (pHRR) during the specimen combustion [35, 39, 40]. The HRR depends on the radiation intensity. The influence of the new compounds A, B, and C on the pHRR plots are tabulated in Table 3.

The peak HRR values of $\mathrm{C} 1, \mathrm{C} 2$, and $\mathrm{C} 3$ composites were reduced by about $24.3 \%, 31.9 \%$, and $37.9 \%$, respectively, compared to the unplanned specimen (PP). In the case of P1-3 specimens pHRR of P3 record the lowest value $\left(1091.48 \mathrm{~kW} / \mathrm{m}^{2}\right)$ compared to the others, while PP specimen has pHRR $\left(1721.17 \mathrm{~kW} / \mathrm{m}^{2}\right)$ higher than specimens M1, M2, and M3 by $10.2 \%, 21.6 \%$, and $26.3 \%$, respectively. 
A. A. Younis

TABLE 3. Cone calorimeter data of blank and blended specimens at $35 \mathrm{~kW} / \mathrm{m}^{2}$.

\begin{tabular}{|c|c|c|c|c|c|c|c|c|c|c|}
\hline Name & PP & P1 & $\mathbf{P 2}$ & P3 & C1 & $\mathrm{C2}$ & C3 & M1 & M2 & M3 \\
\hline $\begin{array}{l}\text { Heat Release Rate } \\
\text { (HRR) } / \mathrm{kW} / \mathrm{m}^{2}\end{array}$ & 579.23 & 444.62 & 379.28 & 368.57 & 425.58 & 386.48 & 344.44 & 421.30 & 409.13 & 400.04 \\
\hline $\begin{array}{c}\text { Total Heat release } \\
\text { Rate }(\mathrm{THRR}) \\
/\left(\mathrm{MJ} / \mathrm{m}^{2}\right)\end{array}$ & 187.80 & 105.50 & 97.70 & 91.00 & 117.00 & 108.50 & 106.70 & 128.70 & 115.80 & 113.10 \\
\hline $\begin{array}{c}\text { Peak Heat Release } \\
\text { Rate }(\mathrm{pHRR}) \\
/\left(\mathrm{kW} / \mathrm{m}^{2}\right)\end{array}$ & 1721.17 & 1658.97 & 1224.09 & 1091.48 & 1303.59 & 1171.98 & 1069.23 & 31545.62 & 1349.41 & 1268.83 \\
\hline $\begin{array}{c}\text { Effective heat of } \\
\text { combustion }(\mathrm{EHC}) \\
/\left(\mathrm{MJ} / \mathrm{m}^{2} \mathrm{~g}\right)\end{array}$ & 15.2 & 8.4 & 7.2 & 6.0 & 7.2 & 6.5 & 6.9 & 8.0 & 7.8 & 7.8 \\
\hline $\begin{array}{c}\text { Time To Flame out } \\
\text { (TTF) /s }\end{array}$ & 246 & 155 & 160 & 175 & 192 & 207 & 216 & 206 & 186 & 139 \\
\hline $\begin{array}{c}\text { Fire performance } \\
\text { index (FPI) } \\
/\left(\mathrm{m}^{2} \mathrm{~s} / \mathrm{kW}\right)\end{array}$ & 0.02 & 0.03 & 0.04 & 0.04 & 0.03 & 0.04 & 0.05 & 0.03 & 0.03 & 0.04 \\
\hline $\begin{array}{c}\text { Initial Weight } \\
\left(\mathrm{W}_{1}\right) / \mathrm{g}\end{array}$ & 17.54 & 16.39 & 16.89 & 16.67 & 17.04 & 17.76 & 17.03 & 16.85 & 16.83 & 16.23 \\
\hline Final Weight $\left(\mathrm{W}_{2}\right) / \mathrm{g}$ & $\mathrm{g} \quad 0.02$ & 1.55 & 1.93 & 2.23 & 0.84 & 1.16 & 1.53 & 1.05 & 1.38 & 1.82 \\
\hline $\begin{array}{l}\text { Total mass lost } \\
\text { (TML)/g }\end{array}$ & 17.52 & 14.84 & 14.96 & 14.44 & 16.20 & 16.60 & 15.50 & 15.80 & 15.45 & 14.41 \\
\hline
\end{tabular}

The most significant data are tabulated in Table3. It showed that pure specimen (PP) produced the highest HRR values $\left(579.23 \mathrm{~kW} / \mathrm{m}^{2}\right)$ compared to the others at heat flux $35 \mathrm{~kW} / \mathrm{m}^{2}$. In case of $\mathrm{P} 1, \mathrm{P} 2$, and $\mathrm{P} 3$ specimens, the heat release rate value decreased by $23.2 \%, 34.5 \%$, and $36.4 \%$, respectively and the same with the other specimens except the weight $\%$. The results indicate that the addition of compounds $\mathrm{A}, \mathrm{B}$, and $\mathrm{C}$ by different weight \% decrease the HRR and pHRR of the blank specimen.

\section{Total heat release (THR)}

The THR has been tabulated in Table 3. Generally, blended PP specimens with different weight $\%$ of compounds $\mathrm{A}, \mathrm{B}$, and $\mathrm{C}$ decreased compared with blank ended specimen. Composite P2 has the lowest THR $\left(91 \mathrm{MJ} / \mathrm{m}^{2}\right)$ compared to the other. This may be returned to the presence of phenyl group which prevent oxygen to penetrate to the ignited surface and so its extinguished.

Effective heat of combustion $\left(\Delta H_{\mathrm{c}, \mathrm{effc}}\right)$

The $\Delta H_{\mathrm{c}, \text { effc }}(\mathrm{kJ} / \mathrm{g})$ can be defined as the total heat emitted when a substance complete combustion. It can be calculated by [41]:

$$
\Delta H_{\mathrm{c}, \mathrm{eff}}=\frac{\text { Total heat release (THR) }}{\text { Total mass loss }(\Delta \mathrm{m})} \cdots(1)
$$


Evaluation The Combustion Properties of The Modified Polypropylene

The heat of combustion versus total mass loss has $(\Delta \mathrm{m})$ been mentioned in Figure 3. The blank specimen has the highest effective heat of combustion value $(10.7 \mathrm{~kJ} / \mathrm{g})$, whereas; P3 specimen has the lowest value $(6.3 \mathrm{~kJ} / \mathrm{g}, \sim 41 \%)$ compared to blank PP specimen. The Figure illustrates that, blended PP with different weight \% of compounds $\mathrm{A}, \mathrm{B}$, and $\mathrm{C}$ lead to decrease the heat of composition, HRR, and pHRR behind increasing the TTI.

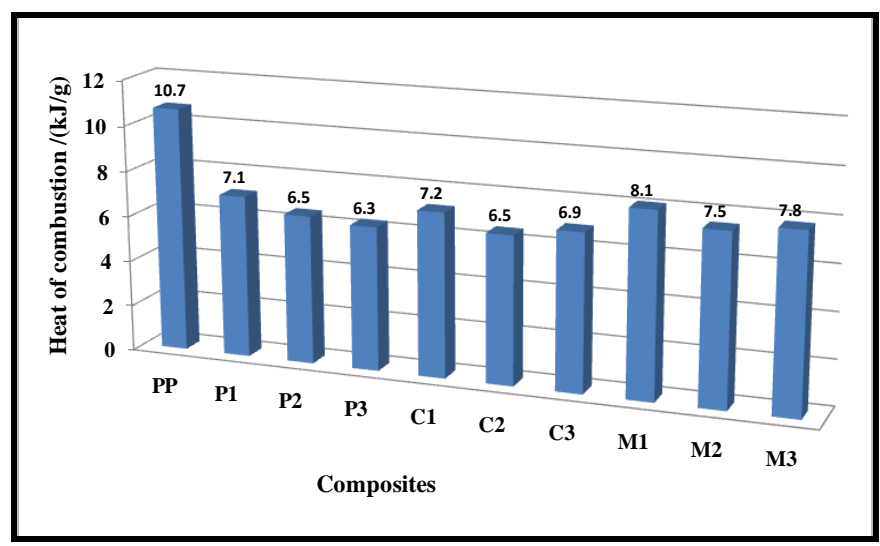

Fig. 3. Explain the effective heat of combustion of blank and blended specimens.

\section{Mass loss and char yield}

Mass loss rate (MLR) is the thermal deterioration rate of the ignition. The new compounds $\mathrm{A}, \mathrm{B}$, and $\mathrm{C}$ have a direct effect in reducing the mass loss rate compared with the blank specimens (Table 3). Tabulated data prove the inverse relationship between weight \% of the compounds and MLR, as the weight \% of new composites increase the MLR decrease and vice versa. The weight of the char residues can be shown in Fig. 4.

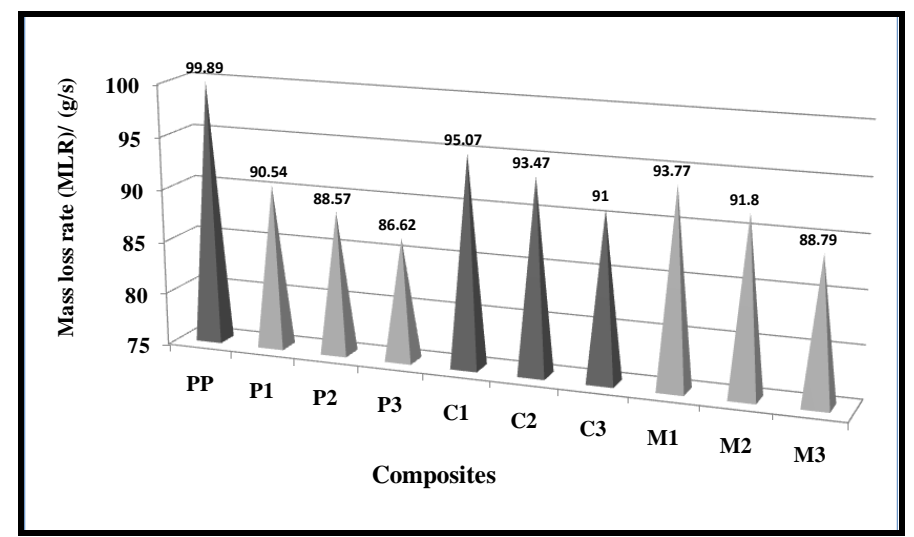

Fig. 4. Association of mass loss rate in cone calorimeter at $35 \mathrm{~kW} / \mathrm{m}^{2}$. 
Figure 5 shows that the relation between the ash residue and weight $\%$, since the ash residue increase by increasing the weight $\%$ of new composites $\mathrm{A}, \mathrm{B}$, and $\mathrm{C}$.

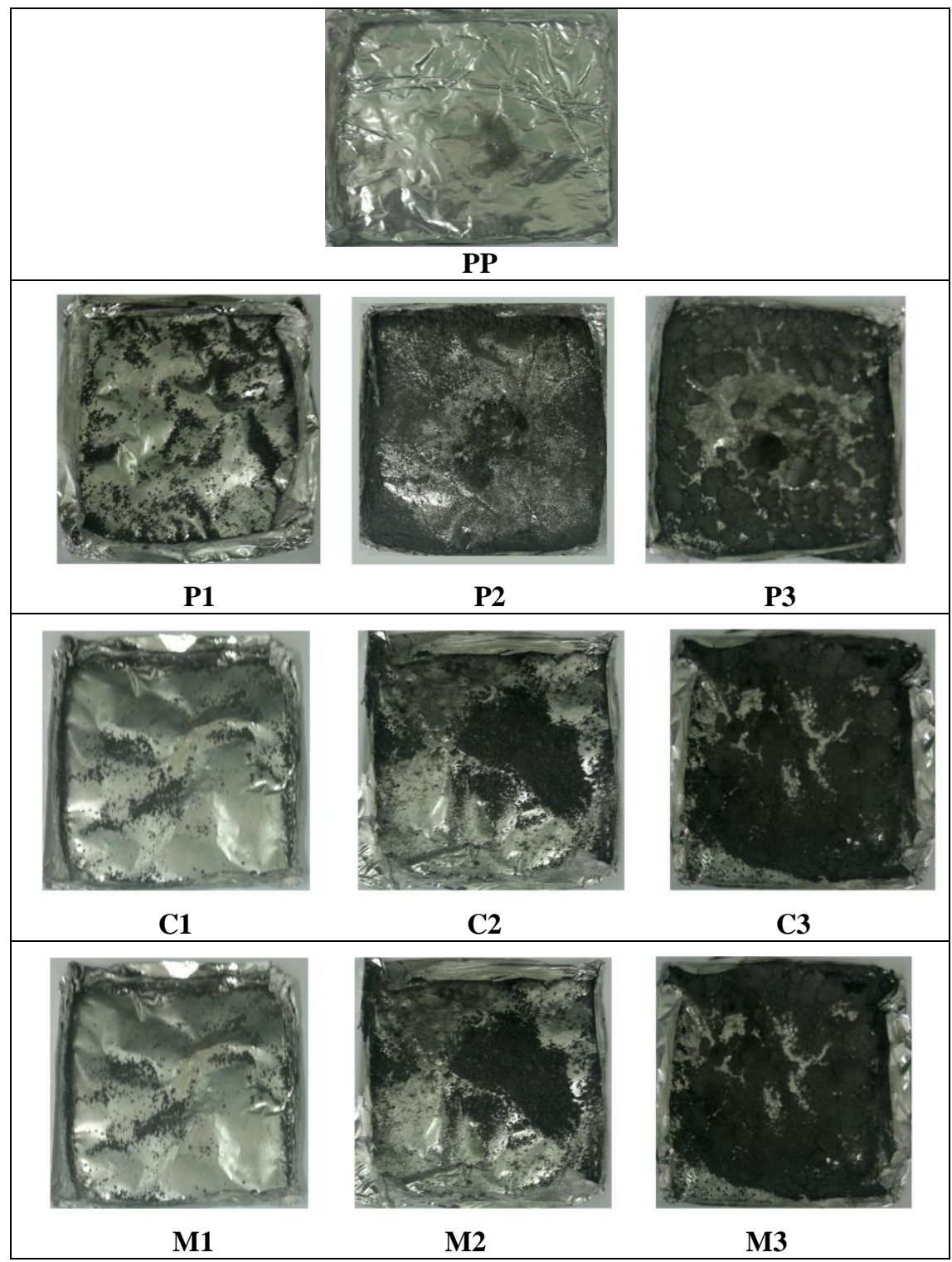

Fig. 5. Digital photographs residues of the specimens after combustion by cone calorimeter instrument at $35 \mathrm{~kW} / \mathrm{m}^{2}$. 


\section{Conclusions}

The thermal performance of the blank and blended specimens was studied by using DSC analysis. This work has explained the main role of the compounds A, $\mathrm{B}$, and $\mathrm{C}$ in improving the ignition characteristics of polypropylene. Both of time to ignite and ash residue increased as the weight $\%$ of compounds $\mathrm{A}, \mathrm{B}$, and $\mathrm{C}$ increased. Heat release rate and peak heat release rate decreased by $\sim 32 \%$ and $35 \%$ when compared to blank specimen, respectively.

\section{References}

1. Yong, T., Yuan, H., Shaofeng, W., Zhou, G., Zuyou, C. and Weicheng, F., Intumescent flame retardant-montmorillonite synergism in polypropylene-layered silicate Nanocomposites. Polym. Int. 52, 1396 (2003).

2. Kobayashi, Y., Otsuki, Y. and Kanai, T., Viscoelastic flow analysis of surface morphology on injection-molded polypropylene, Polym. Eng. Sci. 50, 2182 (2010).

3. Jahani, Y., Comparison of the effect of mica and talc and chemical coupling on the rheology, morphology, and mechanical properties of polypropylene composites, Polym. Adv. Technol. 22, 842 (2011).

4. Li, C., Deng, H., Wang, K., Zhang, Q., Chen, F. and Fu, Q., Strengthening and toughening of thermo-plastic polyolefin elastomer using polypropylene-grafted multiwalled carbon nanotubes, Appl. Polym. Sci. 121, 2104 (2011).

5. Le Bras M., Bugany M., Lefebvre J.M. and Bourbigot S., Use of polyurethanes as charforming agents in polypropylene intumescent formulations, Polym. Int. 49(10), $1115(2000)$.

6. Zhu, J., Morgan, A.B., Lamelas, F.J. and Wilkie, C.A., Fire properties of polystyrene- clay nanocomposites, Chem. Mater. 13, 3771 (2001).

7. Zhu, J., Uhl, F.M., Morgan, A.B. and Wilkie, C.A., Studies on the mechanism by which the formation of nanocomposites enhances thermal stability, Chem. Mater. 13, 4649 (2001).

8. Zanetti, M., Kashiwagi, T., Falqui, L. and Camino, G., Cone calorimeter combustion and gasification studies of polymer layered silicate nanocomposites, Chem. Mater. 14, 881 (2002).

9. Zanetti, M. and Costa, L., Preparation and combustion behaviour of polymer/layered silicate Nanocomposites based upon PE and EVA, Polymer 45, 4367 (2004)

10. Kashiwagi, T., Harris, R.H., Zhang, X., Briber, R.M., Cipriano, B.H., Raghavan, S.R., Awad, W.H. and Shields, H.R., Flame retardant mechanis of polyamide 6-clay Nanocomposites, Polymer 45, 881 (2004). 
11. Qin, H.L., Su,Q.S., Zhang, S.M., Zhao, B. and Yang, M.S., Thermal stability and flammability of polyamide 66/montmorillonite nanocomposltes, Polymer 44, 7533 (2003).

12. Qin H.L., Zhang S.M., Zhao C.G., Feng M., Yang M.S., Shu Z.J. and Yang S.S., Thermal Stability and Flammability of Polypropylene/Montmorillonite Composites, Polym. Degrad. Stab. 85, 807 (2004).

13. Wang, S.F., Hu, Y., Zong, R.W., Tang, Y., Chen, Z.Y. and Fan, W.C., Preparation and characterization of flame retardant ABS/Montmorillonite nanocomposite, Appl. Clay Sci. 25(1), 49 (2004).

14. Tang Y., Hu Y., Wang S.F., Gui Z., Chen Z.Y. and Fan W.C., Intumescent flame retardant-montmorillonite synergism in polypropylene-layered silicate Nanocomposites, Polym. Int. 52, 1396 (2003).

15. Hugget, C., Estimation of rate of heat release by means of oxygen consumption measurements, Fire Mat., 4, 61 (1980).

16. Younis, A.A., Flammability properties of polypropylene containing montmorillonite and some of silicon compounds, Egypt. Jour. Petr. Accepted for publication, 10-Feb2016, in press, http://dx.doi.org/10.1016/j.ejpe.2016.02.003

17. Manias, E., Wu, T.L. and Strawhecker, K., Polypropylene/montmorillonite nanocomposites. Review of the synthetic routes an materials properties, Chem. Mater. 13(10), 3516 (2001).

18. Gilman J.W., Gilman, Flammability and thermal stability studies of polymer layered-silicate (clay) nanocomposites, Appl. Clay Sci. 15, 31 (1999).

19. Tang, Y., Hu, Y., Wang, S.F., Gui, Z., Chen, Z.Y. and Fan, W.C., Intumescent flame retardant-montmorillonite synergism in polypropylene-layered silicate Nanocomposites, Polym. Int. 52, 1396 (2003).

20. Zhao C.G., Qin H.L., Gong F.L., Feng M., Zhang S.M. and Yang M.S., Mechanical, thermal and flammability properties of polyethylene/clay nanocomposites, Polym. Degrad. Stab. 87, 183 (2005).

21. Kashiwagi, T., Harris, R.H., Zhang, X., Briber, R.M., Cipriano, B.H., Raghavan, S.R., Awad, W.H. and Shields, J.R., Flame retardant mechanism of polyamide 6-clay Nanocomposites, Polymer 45, 881 (2004).

22. Wang, S.F., Hu, Y., Zong, R.W., Tang, Y., Chen, Z.Y. and Fan, W.C., Preparation and characterization of flame retardant ABS/montmorillonite nanocomposite, Appl. Clay Sci. 25, 49 (2004).

23. Bonnaud, F.L., Alexandr,e M., Lopez-Cuesta, J.M. and Duboi, S. P.H., New prospects in flame retardant polymer materials :From fundamentals to nanocomposites. Mat. Sci. Eng. 63, 100 (2009). 
24. Gilman, J.W., Jackson, C.L., Morgan, A.B., Harris, R., Manias, E., Gannelis, E.P., Wuthenow, M., Hilton, D. and Phillips, S.H., Flammability properties of polymer-layered-silicate nanocomposites, polypropylene and polystyrene nanocomposites, Chem. Mater. 12, 1866 (2000).

25. Qin, H.L., Zhang, S.M., Liu, H.J., Xie, S.B., Yang, M.S. and Shen, D.Y., Photooxidative degradation of polypropylene/montmorillonite nanocomposites, Polymer, 46, 3149 (2005).

26. Younis, A.A., Nour, M.A. and El-Nagar, Kh., Studying the effect of phosphorylated sol-gel on polyester fabric as flame-retardant coating. Elixir Appl. Chem. 70, 24230 (2014).

27. Huggett, C., Estimation of rate of heat Release by means of oxygen consumption measurements, Fire and Mat. 4(2), 61 (1980).

28. Parker, W., Calculations of the Heat Release Rate by Oxygen Consumption for Various Applications, Gaithersburg, NBSIR 81-2427, National Bureau of Standards, (1982).

29. Reaction to fire tests-heat release, smoke production and mass loss rate-part 1: heat release rate (cone calorimeter method). ISO 5660-1. International Organization for Standardization, Geneva, Switzerland, (2002).

30. Tata, J., Alongi, J., Carosio, F. and Frache A., Optimization of the procedure to burn textile fabrics by cone calorimeter: Part I. Combustion behavior of polyester. Fire Mater. 35(6), 397 (2011).

31. Babrauskas, V. and Wetterlund, I., Optimising foil thickness for cone calorimeter tests of furniture composites, Fire Saf. 22, 417 (1994).

32. Hirschler M.M., In Heat Release from Plastic Materials, Heat Release in Fires, V. Babrauskas, S.J. Grayson (eds), Chapter 12a, Else. App. Sci., London, UK, 375 (1992).

33. Babrauskas, V., In The Cone Calorimeter, Heat Release in Fires, Babrauskas V, Grayson SJ (Eds), Chapter 4, Else. App. Sci. London, UK, 61 (1992).

34. Schartel, B., Bartholmai, M. and Knoll, U., Some comments on the main fire retardancy mechanisms in polymer nano-composites, Polym. Adv. Technol. 17, 772 (2006).

35. Huang, N., Chen, Z., Wang, J. and Wei, P., Synergistic effects of sepiolite on intumescent flame retardant polypropylene, Expr. polym. Lett. 4(12), 743 (2010).

36. Zhong-jun, S.H.U., et al., Fire performances of a kind of PVC composite board by Cone Calorimeter Test. Chem. Mater. Const. 6, 23 (2003).

37. Schartel B., Bartholmai, M. and Knoll, U., Some comments on the main fire retardancy mechanisms in polymer nano-composites. Polym. Adv. Technol. 17, 772 (2006). 
38. Hirschler, M.M. and Shalir, S., Measurements of cable fire properties by using heat release equipment. Proceedings of flame retardants 92, plastics and rubber institute fire retardant tech. Mtg. Jan. 22-23, Elsevier, London, UK, 77 (1992).

39. ASTM E 1354. Standard Test Method For heat and Visible Smoke Release Rates for Materials and Products Using an Oxygen Consumption Calorimeter, (1992).

40. Yun, W.A.N.G., et al., The application of cone calorimeter on the study of fire retarded materials, Chin. Peopl. Arm. Pol. Forc. Acad., 1, 31 (2006).

41. Morandini, F., Perez-Ramierz, Y., Tihay, V.S., Santoni, P., and Barboni, T., Radiant, convective and heat release characterization of vegetation fire, Int. J. Therm. Sci. 70, 83 (2013).

(Received 26/1/2017; Accepted 12/2/2017) 


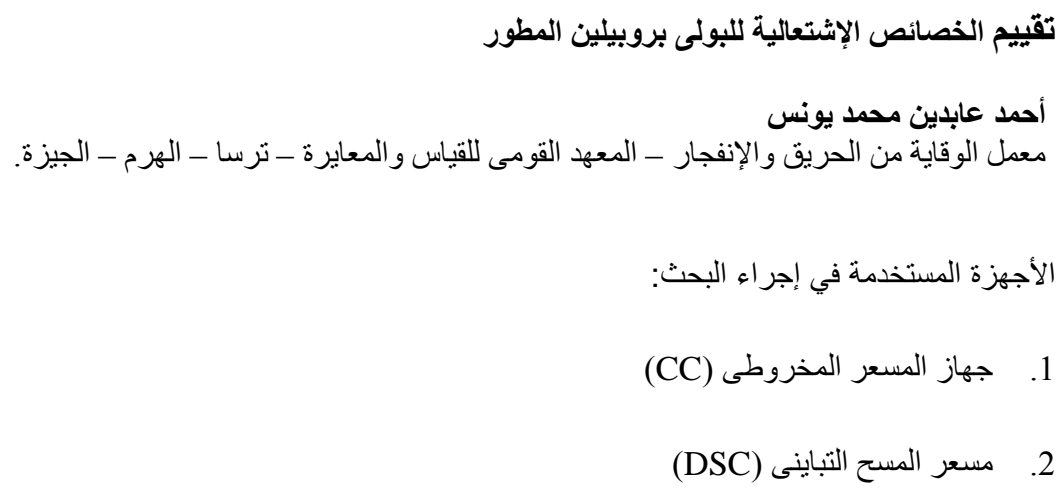

3.

4. جهاز الحقن Morgan Press Injection Instrument (USA)

يهدف هذا البحث إلى دراسة وتقييم الخصائص الإشتعالية للبولى بروبيلين المطور بإستخدام أجهزة مسعر

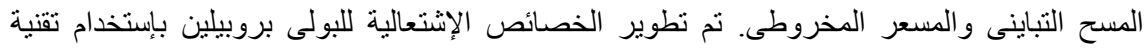

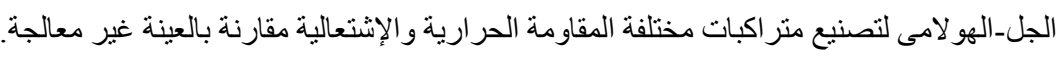
تم تحضير مركبات A, B, and C ثم خلطها مع البولى بروبيلين بنسب مختلفة لإتمام النسبة الكلية بنسبة

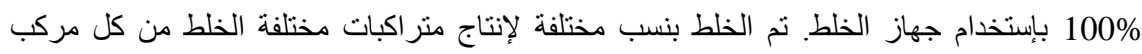
بنسب:97.5:2.5, 95.0:5.0, and 92.5:7.5\% أثبت اختبار المسعر الحرارى إختلاف كلاً من القمم والحر ارة المتصاعدة من العينة عند

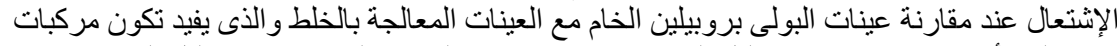

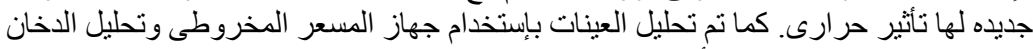

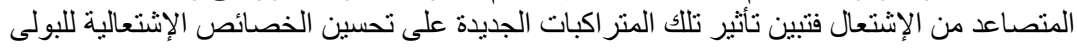

بروبيلين. 